\title{
Characterization of the RepFVII Replicon of the Haemolytic Plasmid pSU233: Nucleotide Sequence of an incFVII Determinant
}

\author{
By JAVIER LÓPEZ, JOSE C. RODRÍGUEZ,* I. ANDRÉS AND J. M. ORTIZ \\ Departamento de Biología Molecular, Facultad de Medicina, Polígono de Cazoña s/n, \\ 39011 Santander, Spain
}

(Received 22 December 1988; revised 20 February 1989; accepted 16 March 1989)

We have isolated a replication region (designated RepFVII) from the IncFVII plasmid, pSU233. Hybridization experiments showed that RepFVII has high homology to the RepFIII replicon of the plasmid pSU316 and, therefore, that pSU233 is another member of the RepFIIA family. We have also located the incompatibility gene (incFVII) from RepFVII. The analysis of its sequence revealed the same organization described for several other replicons belonging to the same family.

\section{INTRODUCTION}

Bacterial plasmids able to synthesize an F-like pilus have been grouped within the ' $F$ complex' (Bradley et al., 1980; Willets \& Skurray, 1980). Initial results indicated that there were no relationships among the replication regions of IncF plasmids belonging to different incompatibility groups (Sharp et al., 1973). However, Bergquist et al. (1986) showed that three replicons previously described for IncFI plasmids, namely RepFIA, RepFIB and RepFIC, are widely distributed among IncF plasmids belonging to six incompatibility groups (IncFI to IncFVI). The RepFIIA replicon of IncFII plasmids is homologous to RepFIC and plasmids homologous to RepFIC/RepFIIA have been classified as belonging to the RepFIIA family (Saadi et al., 1987).

During the study of the incompatibility properties of haemolytic plasmids, de la Cruz et al. (1979) reported the existence of a plasmid able to synthesize an F-like pilus and compatible with all previously known IncF plasmids. This plasmid, named pSU233, was classified as IncFVII.

In this paper we report the isolation of a replicon, RepFVII, from pSU233. RepFVII shows homology with RepFIII, a member of the RepFIIA family (Bergquist $e t$ al., 1986; J. Lopez and others, unpublished), and thus belongs to this family. In addition, a fragment encoding the IncFVII incompatibility has been located and its nucleotide sequence determined. A comparison with several other IncF plasmids incompatibility genes is presented.

\section{METHODS}

Bacterial strains and plasmids. The Escherichia coli derivative $\mathrm{DH} 5 \alpha$ ( $\mathrm{F}^{-}$endAl hsdRI7 supE44 thi-1 recAl gyrA96 relA1 (lacZYA-argF)U169 $\phi 80 \mathrm{~d}$ lacZ M15; Bethesda Research Laboratories) was the bacterial strain used for the experiments described in this work. The plasmid vectors used were pGEM-3Z (Promega Biotec) and pHGS399 (Takeshita et al., 1987). pSU3040 is a plasmid containing the RepFIII replicon and has been described previously (Rodriguez et al., 1983). pSU221 is a Tn802 insertion derivative of the IncFVII haemolytic plasmid pSU233 and was described by de la Cruz et al. (1979). pSU502 is an IncFVI plasmid also described by de la Cruz $e t$ al. (1979). The plasmids pSU3201, pSU3202, pSU3203 and pSU3204 were constructed during this work (see Results).

DNA manipulations. Plasmid DNA was isolated after caesium chloride/ethidium bromide density gradient centrifugation of lysates obtained by the alkaline procedure described by Ish-Horowicz \& Burke (1981). The purification of restriction fragments from either agarose or acrylamide gels was done as described by Maniatis $e t$ 
al. (1982). The conditions of digestion, ligation and transformation have been previously reported (Andres et al., 1987). When intramolecular ligations were required, the DNA concentrations were calculated as suggested by Perbal (1984).

The transfer of DNA fragments to nitrocellulose filters and subsequent hybridization were basically done according to Meinkoth \& Wahl (1984). The hybridizations were carried out at $65^{\circ} \mathrm{C}$ in $6 \times \mathrm{SSC}, 1 \times$ Denhardt's reagent, $100 \mu \mathrm{g}$ denatured herring sperm DNA $\mathrm{ml}^{-1}$ and $0.1 \% \mathrm{SDS}$. $(1 \times \mathrm{SSC}$ is $0.15 \mathrm{M}$ - $\mathrm{NaCl}$ plus $0.015 \mathrm{M}$-sodium citrate; $1 \times$ Denhardt's reagent is $0.02 \%$ bovine serum albumin, $0.02 \%$ Ficoll, $0.02 \%$ polyvinylpyrrolidone.) Before exposure the filters were washed at a final stringency of $0.2 \times$ SSC.

Incompatibility tests. Competent cells harbouring the resident plasmid were transformed and selected only for the incoming plasmid. Three transformant colonies were resuspended in L-broth and, after appropriate dilutions, plated onto L-agar plates without selection. The loss of any of the plasmids was tested by transferring 50 colonies from each plate to L-agar plates containing the appropriate antibiotics. To rule out any recombinational event, DNA preparations from ten individual colonies were analysed by agarose gel electrophoresis.

DNA sequence determinations. The Sau3A fragment containing the inc gene was cloned within the Bam $\mathrm{HI}$ site of the vector pGEM-3Z (Promega Biotec) and sequenced by the enzymic chain termination method of Sanger adapted for double-stranded DNA (Korneluk et al., 1985).

\section{RESULTS AND DISCUSSION}

\section{Definition of RepFVII, the minimal IncFVII replicon}

pSU221 is a Tn3 insertion derivative of the IncFVII haemolytic plasmid pSU233 (de la Cruz et al., 1979). To test whether IncFVII plasmids have any homology to the plasmids belonging to the RepFIIA family, we digested pSU221 with the endonuclease EcoRI and probed the digest with a $2.9 \mathrm{~kb} \mathrm{Bg} / \mathrm{II}-\mathrm{XbaI}$ fragment containing part of the minimal replicon of the IncFIII plasmid pSU316 (Rodriguez et al., 1983). The hybridization experiment showed a region of strong homology in an EcoRI fragment $15 \mathrm{~kb}$ in size. No other fragments showed any homology (data not shown). This is the fragment known to contain the inserted Tn3 (de la Cruz et al., 1979). If the homology corresponds to a functional replication region, the recircularization of the $15 \mathrm{~kb}$ fragment would result in an ampicillin-resistant miniplasmid. Thus, the EcoRI digestion was ligated in conditions favouring the recircularization of the fragments and the mixture was used to transform competent $E$. coli cells selecting for ampicillin resistance. As expected, a $15 \mathrm{~kb}$ miniplasmid was obtained. This miniplasmid was termed pSU3201. Its map is shown in Fig. 1.

The homology between pSU3201 and RepFIII, the replicon of the IncFIII plasmid pSU316, is located in two Pst I fragments, 4.2 and $1.1 \mathrm{~kb}$ in size respectively (Fig. 2, A). These Pst $\mathrm{I}$ fragments are contiguous. Part of the $4.2 \mathrm{~kb}$ fragment corresponds to the bla gene of the Tn 802 transposon. In order to confirm that this fragment is a functional replication region, we constructed the miniplasmid pSU3202 by intramolecular ligation of the BglII-BamHI fragment shown in Fig. 1.

\section{Isolation and sequencing of an IncFVII determinant}

When comparing the nucleotide sequences of four replicons belonging to the RepFIIA family, Saadi et al. (1987) defined alternating regions of homology (HRs) and nonhomology (NHRs). One of the regions of conserved homology (HRII in Saadi et al., 1987) corresponds to the incompatibility gene inc. In order to locate this gene in the RepFVII replicon, we digested pSU3201 with several restriction endonucleases; the digests were blotted onto nitrocellulose filters and probed with a $0.5 \mathrm{~kb}$ Pst I fragment which contains the incompatibility gene of the plasmid pSU316 (Rodriguez et al., 1983). The results shown in Fig. 2 (B to E) indicate that the minimal fragment of pSU3201 that showed homology with the incFIII gene is a BglII-SalI fragment of $0.84 \mathrm{~kb}$. The restriction map of this fragment is identical to the same region of $\mathrm{R} 100$, an IncFII plasmid also belonging to the RepFIIA family (Fig. 1). The $0.84 \mathrm{~kb}$ fragment was cloned in pHGS399 to produce the plasmid pSU3204. As shown in Table 1, pSU3204 is strongly incompatible with its parent plasmids (i.e. pSU221, pSU3201 and pSU3202) but compatible with the plasmids pSU3040 and pSU502 belonging respectively to the IncFIII and IncFVI incompatibility groups. 


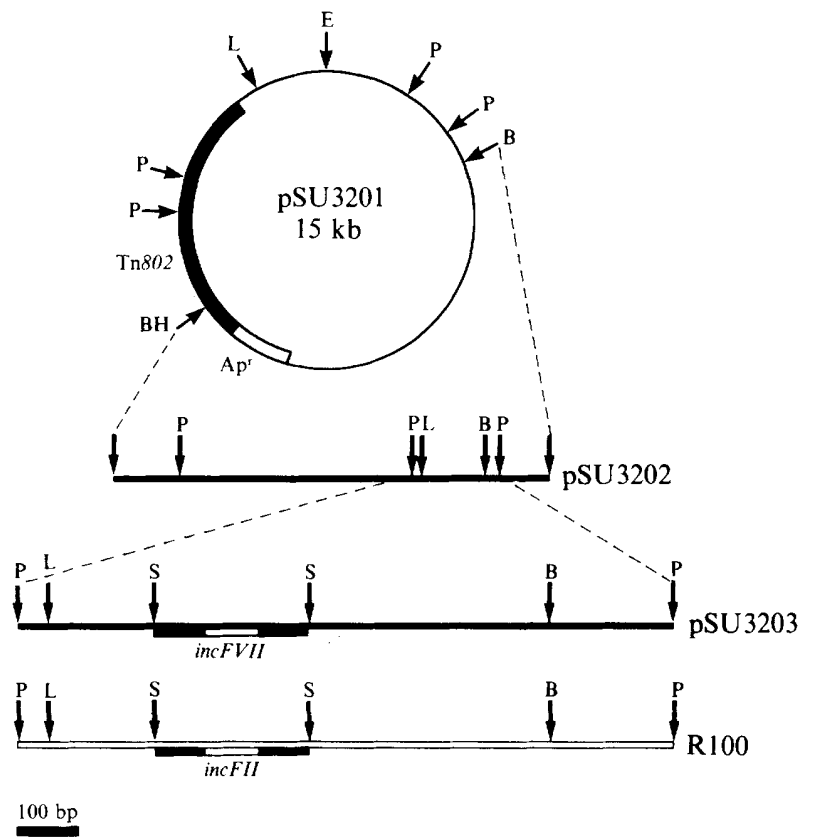

Fig. 1. Physical map of the plasmids constructed during this work. Both pSU3201 and pSU3202 are autonomously-replicating miniplasmids obtained by deletions of pSU221. pSU3203 is a pBR322 clone containing a $1.1 \mathrm{~kb}$ Pst I fragment from pSU3202. The comparison of the PstI fragment of pSU3203 with the same region of R100 (Rosen et al., 1980) is also shown. Restriction sites are: P, PstI; L, SalI; E, EcoRI; B, BglII; BH, BamHI; S, Sau3A.
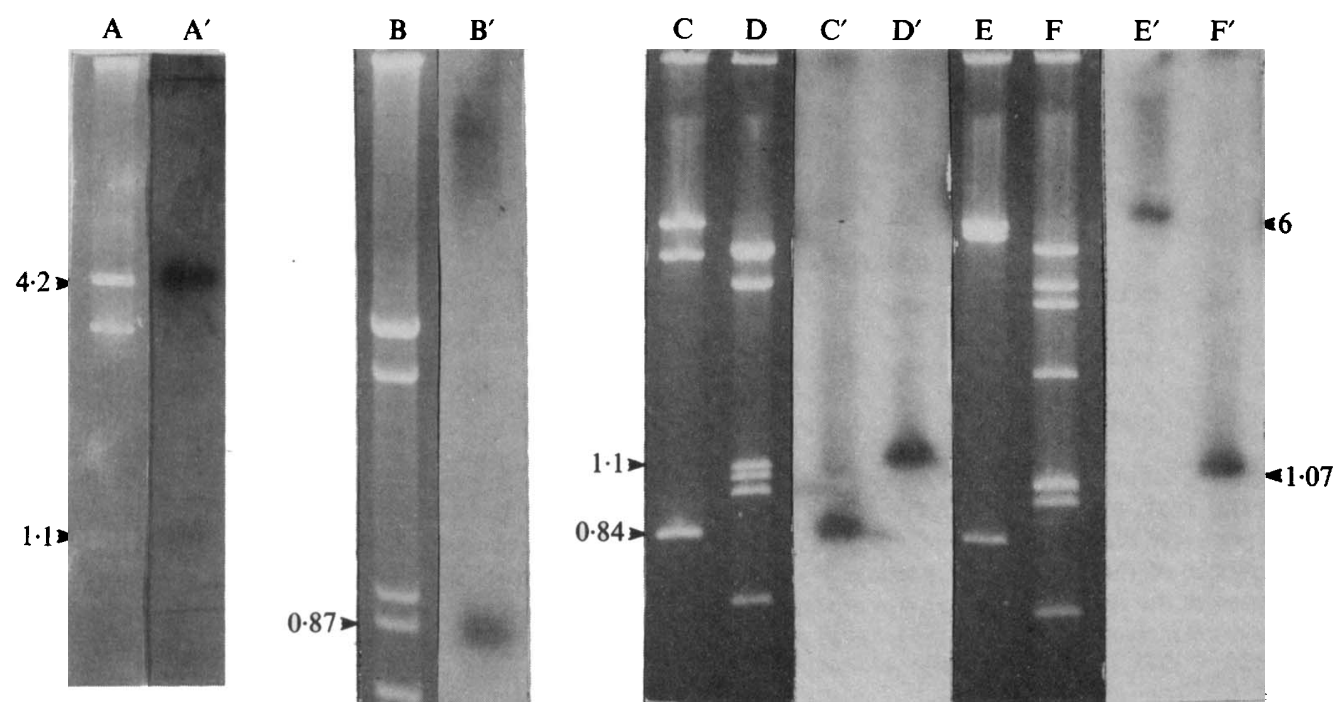

Fig. 2. Southern blot hybridizations of pSU3201. Digests were transferred to nitrocellulose filters as described in Methods. The arrows at the sides indicate the fragments showing homology. The size of these fragments is also indicated. The different parts of the figure correspond to different gels. A and $\mathbf{A}^{\prime}$, pSU3201 digested with Pst I and hybridized with a $2.9 \mathrm{~kb}$ fragment of the RepFIII replicon of pSU316 (Rodriguez et al., 1983). B and B', Double digeston PstI-BgllI of pSU3201 hybridized with a $0.5 \mathrm{~kb}$ probe containing the incFIII gene (Rodriguez et al., 1983). The same probe was used for hybridizing with the following digestions of pSU3201: $\mathrm{C}$ and $\mathrm{C}^{\prime}$, SalI-BglII; D and D', PstI; E and E', BamHIBglII; F and F', SalI-PstI. 


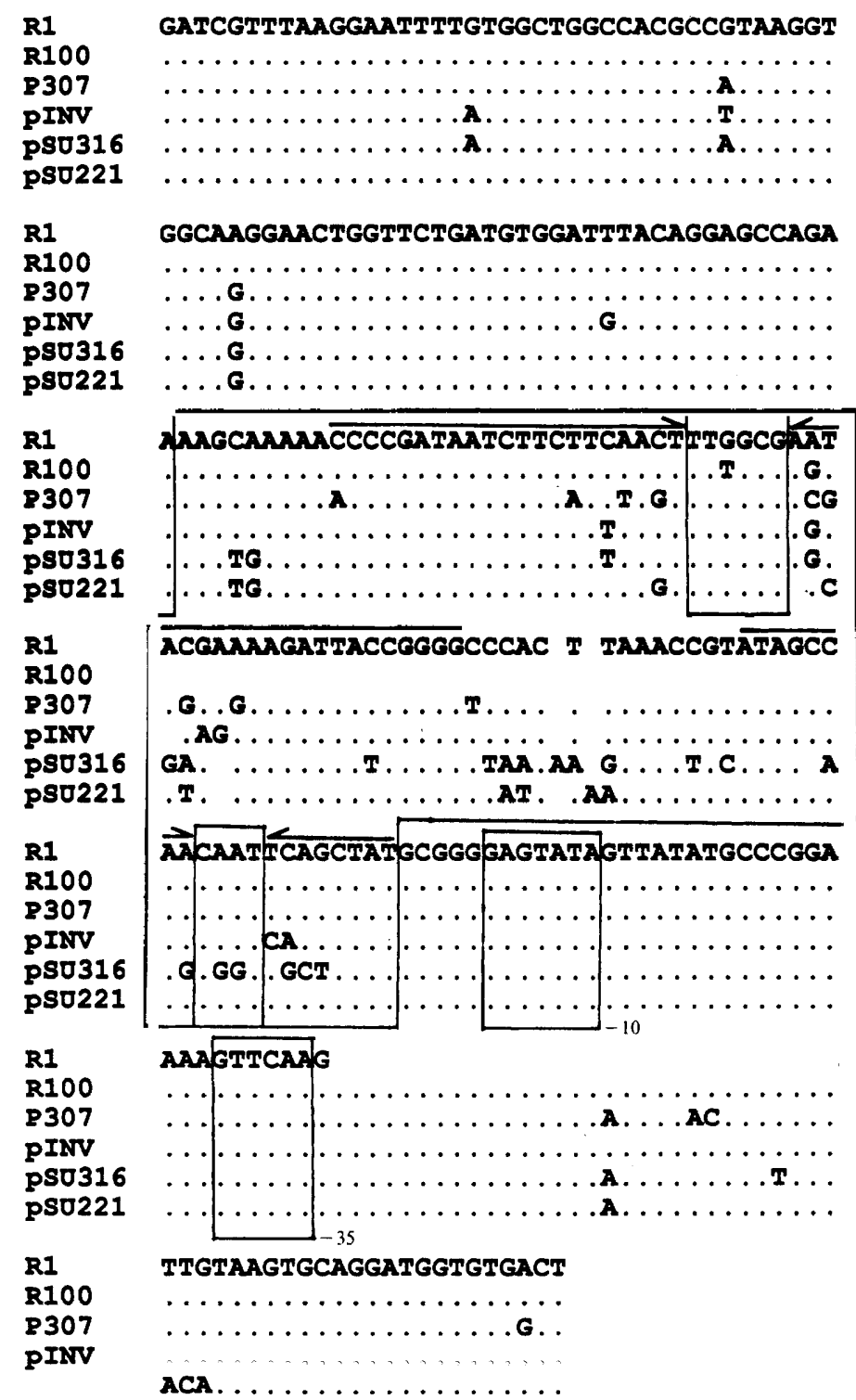

Fig. 3. Comparison of the nucleotide sequences of the Sau3A fragment containing the inc gene of several IncF plasmids. The gene is transcribed leftwards. Boxes labelled -35 and -10 represent respectively the -35 and -10 consensus promoter regions (Rosenberg \& Court, 1979). The coding sequence of the IncRNA of plasmid Rl is indicated by the large box. Arrows above the sequence represent the stems of the two loops of the IncRNA which are indicated by the small boxes between the arrows (Gerhart et al., 1986). Sequences were taken from Rosen et al. (1980; R1 and R100), Saadi et al. (1987; P307), López et al. (unpublished; pSU316) and Silva et al. (1988; pINV).

Comparison of the incompatibility genes of several IncF plasmids

The incompatibility genes of all the IncF plasmids so far mapped are contained in a $262 \mathrm{bp}$ Sau3A fragment. There is an analogous fragment within the $0.84 \mathrm{~kb}$ fragment of pSU221 which expresses the IncFVII phenotype. The nucleotide sequence of this Sau3A fragment of pSU3201 was determined and is shown in Fig. 3. 
Table 1. Incompatibility properties of pSU3204

Plasmid pSU3204 was always used as the donor plasmid. At least 150 colonies of each pair were assayed for the presence of plasmid.

$\begin{array}{cccc}\text { Resident plasmid } & \begin{array}{c}\text { Percentage } \\ \text { plasmid loss }\end{array} & \text { Plasmid lost } & \text { Incompatibility } \\ \text { pSU221 } & 100 & \text { pSU221 } & + \\ \text { pSU3201 } & 100 & \text { pSU3201 } & + \\ \text { pSU3202 } & 100 & \text { pSU3202 } & + \\ \text { pSU3040 } & 0 & \text { none } & - \\ \text { pSU502 } & 0 & \text { none } & -\end{array}$

The inc gene of replicons belonging to the RepFIIA family encodes a small RNA molecule. This RNA is expressed constitutively from its own promoter (Rosen et al., 1981; Stougaard et al., 1981). The existence of this promoter seems to be essential for the controlled replication of RepFIIA-family replicons. As expected, the consensus sequences of the -35 and -10 regions of the promoter are conserved in the nucleotide sequence of pSU221 as well (Fig. 3).

The study of the secondary structure of the IncRNA of the IncFII plasmid R1 revealed the existence of two loops, namely loop I and loop II. Loop II is presumably involved in the recognition of the target RNA. In fact many copy number mutations have been mapped in positions that would alter loop II structure (Giskov \& Molin, 1984; Gerhart et al., 1986). pSU221 presents three mutations in the region coding for the stem of loop II. These mutations are good candidates for the change of incompatibility group of the plasmid pSU221.

In conclusion, the RepFVII replicon of pSU221 is another member of the RepFIIA family of replicons. The incFVII gene shows very few changes with respect to other RepFIIA-family plasmids. Our results, together with other studies on the evolution of RepFIIA-family plasmids (for review see Saadi et al., 1987), indicate that the divergence to incompatibility groups is a very recent event. Such a rapid divergence to different incompatibility phenotypes suggests that incompatibility is probably an undesirable side-effect of the replication control mechanisms. Another interesting effect of this rapid evolution is that the conservation of most of the sequences in the replication region would allow exchange of genes among different replicons. As suggested by Saadi et al. (1987), this shuffling of replication genes would probably increase the 'survival value' of IncF plasmids.

This work was supported by grant $0007 / 85$ from the Comision Asesora de Investigacion Cientifica y Tecnica (CAICYT). J.L. is a predoctoral recipient of a grant from the Spanish Ministry of Education (Plan de Formacion del Personal Investigador).

\section{REFERENCES}

ANDres, I., Rodriguez, J. C., Barbadillo, J. \& ORTIZ, J. M. (1987). Identification and expression of a copy number control gene in the IncFIII hemolytic plasmid pSU316. Journal of Bacteriology 169, 24052409.

Bergquist, P. L., SAAdi, S. \& MaAs, W. K. (1988). Distribution of basic replicons having homology with RepFIA, RepFIB and RepFIC among IncF plasmids. Plasmid 15, 19-34.

BRADLEY, D. E. (1980). Morphological and serological relationships of conjugative pili. Plasmid 4, 155169.

de la Cruz, F., Zabala, J. C. \& Ortiz, J. M. (1979). Incompatibility among $\alpha$-hemolytic plasmids studied after inactivation of the $\alpha$-hemolysin gene by transposition of Tn802. Plasmid 2, 507-519.

GerharT, E., WAGNER, H. \& NordSTRÖM, K. (1986).
Structural analysis of an RNA molecule involved in replication control of plasmid R1. Nucleic Acids Research 14, 2523-2538.

Giskov, M. \& Molin, S. (1984). Copy mutants of plasmid R1: effects of base pair substitution in the copA gene on the replication control system. Molecular and General Genetics 194, 286-292.

ISH-HoROWICZ, D. \& BURKE, J. F. (1981). Rapid and efficient cosmid cloning. Nucleic Acids Research 9, 2989-2998.

Korneluk, R. G., Quan, F. \& Gravel, R. A. (1985). Rapid and reliable dideoxy sequencing for doublestranded DNA. Gene 40, 317-323.

Maniatis, T., Fristsch, E. F. \& SAMbrook, J. (1982). Molecular Cloning: a Laboratory Manual. Cold Spring Harbor, NY: Cold Spring Harbor Laboratory. 
Meinkoth, J. \& WaHL, G. (1984). Hybridization of nucleic acids immobilized on solid supports. Analytical Biochemistry 138, 267-284.

Perbal, B. (1984). Ligation. In A Practical Guide to Molecular Cloning, pp. 248-253. New York: Wiley.

Rodriguez, J. C., ANDRes, I., DE la CRUZ, F., NAVAS, J., Pulgar, G. \& Ortiz, J. M. (1983). Genetics of the replication and maintenance functions of the hemolytic plasmid pSU316. Cloning of an IncFIII determinant. Plasmid 10, 175-193.

Rosen, J., Ryder, T., INOKuChI, H., OHTSubo, H. \& OHTSUBO, E. (1980). Genes and sites involved in replication and incompatibility of an R 100 plasmid derivative based on nucleotide sequence analysis. Molecular and General Genetics 179, 527-537.

Rosen, J., Ryder, T., OHtsubo, E. \& OHTSUBO, H. (1981). Role of RNA transcripts in replication, incompatibility and copy number control in antibioic resistance plasmid derivatives. Nature, London 290, 794-797.

Rosenberg, M. \& Court, D. (1979). Regulatory sequences involved in promotion and termination of transcription. Annual Review of Genetics 13, 319-353.

SaAdi, S., MaAs, W. K., Hill, D. \& Bergquist, P. L. (1987). Nucleotide sequence of RepFIC, a basic replicon present in IncFI plasmids P307 and F and its relation to the RepA replicon of IncFII plasmids. Journal of Bacteriology 169, 1836-1846.
Sharp, P. A., Cohen, S. N. \& Davidson, N. (1973). Electron microscope heteroduplex studies of sequence relations among plasmids of Escherichia coli. II. Structure of drug resistance (R) factors and $\mathbf{F}$ factors. Journal of Molecular Biology 75, 235-255.

Silva, R. M., SAadi, S. \& MaAs, W. K. (1988). A basic replicon of virulence-associated plasmids of Shigella spp. and enteroinvasive Escherichia coli is homologous with a basic replicon in plasmids of IncF groups. Infection and Immunity 56, 836-842.

StougaARd, P., Molin, S. \& Nordstrom, K. (1981). RNAs involved in copy-number control and incompatibility of plasmid R1. Proceedings of the National Academy of Sciences of the United States of America 78, 6008-6012.

Takeshita, S., Sato, M., Toba, M., Masahashi, W. \& Hashimoto-GoToH, T. (1987). High-copy-number and low-copy-number plasmid vectors for $l a c Z \alpha-$ complementation and chloramphenicol- or kanamycin-resistance selection. Gene 61, 63-74.

WILleTs, N. \& SkURRAY, R. (1980). The conjugation system of F-like plasmids. Annual Review of Genetics 14, 41-76. 